\title{
INHABITED SACRISTIES IN MEDIEVAL ENGLAND: THE CASE OF ST MARY'S, WARWICK
}

\author{
James Willoughby, FSA
}

James Willoughby, FSA, New College, Oxford OXI 3BN, UK. E-mail: james.willoughby@history. ox.ac.uk

A transcript survives of the oath sworn in 1465 by the lay sacristan of the collegiate church of St Mary at Warwick on the occasion of his taking office. His duties are spelled out in detail, and include the striking requirement that he spend each night in the sacristy for the better security of the treasures. This paper prints the oath and aims to place it in its institutional context. The medieval sacristy at Warwick survives and details of the oath illuminate details of the architecture. Similar first-floor vestries are known elsewhere, and the suggestion is made that some other churches might also have had inhabited sacristies.

The dean and chapter of the great collegiate church of St Mary at Warwick were protective of their college's supposed exemption from diocesan jurisdiction. As a consequence, friction between the college and the bishop of Worcester was a recurrent aspect of the church's medieval life. ${ }^{\mathrm{I}}$ Continuing discord eventually brought about the imposition on the college of two new sets of statutes. The first were issued by Bishop William Whittlesey in 1367 and were addressed to inequities in prebendal incomes and the recovery of lost possessions. The second set was issued by Bishop Thomas Bourgchier in I44I and reasserted diocesan authority after a period of local autonomy under Dean Thomas Yonge. ${ }^{2}$ The place to begin this account of the role of the sacristan at Warwick is with these statutes of Bishop Bourgchier, in that among them are several that were directed towards regulating the safe husbandry of the college's treasures. ${ }^{3}$ First, it was enjoined upon the dean and chapter that they keep at all times an indentured inventory of the church's moveable goods. One copy of the inventory was to remain with the keeper of the jewels, vestments, books and ornaments, and the other was to be kept in 'the chest with three locks'. The statutes provided separately for this chest: it was to be set up in the treasury and used for the safe-keeping of the college's common seal, for the keys to the

I. An appeal was made to Canterbury against the visitorial rights of the diocesan during the episcopate of Godfrey Giffard (I268-I302), and was settled in I290 when Thomas de Sodyngton was appointed dean, having first formally sworn obedience to the bishop in the cathedral church at Worcester. For the dispute with first the bishop and then the archdeacon, see Haines 1965, 27-8.

2. Thomas Yonge had been admitted to a prebend at St Mary's on I2 June I39I and was elected dean on 27 Sept 1395, his estate being ratified on 24 Oct 1398 . He held office until his death, which had occurred by Io Apr I432. His career is given in summary by Fonge 2004, 457-8.

3. These statutes (referred to as 'statutes' henceforth) are transmitted uniquely in PRO, E 315/492, fols 5-IOv; Fonge 2004, 373-95 (App I). The earlier statutes of Bishop Whittlesey are transmitted by the same manuscript (fols I-4v); also by the cartulary of St Mary's (PRO, E I64/22) and by the Black Book of Woodcote (WRO, CR 26/4); Fonge 2004, I43-55 (no. I24). 
muniment chests and for the cash that remained after the annual expenses of the college had been met. The three keys were to be held by the dean, the canon treasurer and a resident canon. ${ }^{4}$ The church goods themselves were to be kept only in the treasury under faithful guard: et omnia iocalia, ornamenta, vestimenta et libri ecclesie predicte infra thesaurariam predictam et non alibi sub fideli diligenter custodia statuimus conseruari. ${ }^{5}$

While the dean and chapter may have been immediately obedient to this injunction, the first custodian of the treasures for whose activities there is evidence was a man by the name of Thomas Hillusley, who was sworn to the office of lay sacristan on Friday 22 February $1464 / 5$. An inventory of goods in the church was drawn up at the same time, in the form of a bipartite indenture between Hillusley, acting as receiver, and the dean, William Berkeswell, all other canons then being absent. ${ }^{6}$ Written on the dorse of this inventory is a most unusual document: the oath that Hillusley swore on the occasion of his appointment (printed in Appendix I below). This oath lays out the terms of the sacristan's employment and his duties and responsibilities. It therefore allows one to reconstruct the activities of the sacristan of a great collegiate church in sometimes picturesque detail, as it also allows one to interpret certain features of the existing fabric of St Mary's in relation to this office since, as the oath shows, the sacristan was required to sleep in the church. It is the intention here to explore all these aspects of the evidence before turning in the final part of this paper to consider architectural features in other churches which echo those at St Mary's, and which might allow the speculation that similar provisions to the custodial arrangements at Warwick could have been encountered elsewhere.

The oath's foremost condition was one of obedience to the dean and chapter, and duties that are a concomitant of obedience are stated in other rubrics. For example, Hillusley swore to inform the dean and chapter of any information prejudicial to the foundation as soon as he might learn it, and he was enjoined to keep the college's confidences and any secrets of the place to which he himself might become privy. He swore to keep safe all the church's treasures, 'money, jewels, books and vestments', and all other church goods, and neither take any item out of the church nor bring in any other man's goods for safe keeping without the prior assent of the dean and chapter. ${ }^{7}$ The attributes that were desirable in a sacristan were spelled out: he should be sober and quietly behaved, foregoing taverns and dice-playing and hunting and fishing, and his attire should also be sober, without bolsters in his clothing or pikes on his shoes or long dagger at his side. Instead he was to clothe himself 'like a clerk', wearing surplice ('habite') and be available to assist at divine service when required.

4. Statutes, 3-5.

5. Statutes, 4: 'and we ordain that all the jewels, ornaments, vestments and books of the aforesaid church are to be kept carefully under faithful guard in the aforesaid treasury and nowhere else'.

6. PRO, E I54/I/46; see also Appendix I below.

7. The church's numerous relics would have therefore been his responsibility, as also the library books that belonged to the dean and chapter and not just the service books. Some of the books, the inventory shows, were kept in an iron-bound coffer, having iron rings at each end 'to heave it by', and which stood in the 'house before the chapter-house'; this was the lobby on the north side of the choir, which communicated directly with the little chapter-house built against the north wall. Although the books so mentioned may have been service books not already disposed around the choir, the likelihood is that this was in fact the communal collection of library books, which had numbered 9 volumes in 1408 and was not much more than double that number in I465. The evidence for the library at St Mary's is brought together by Willoughby, forthcoming. 


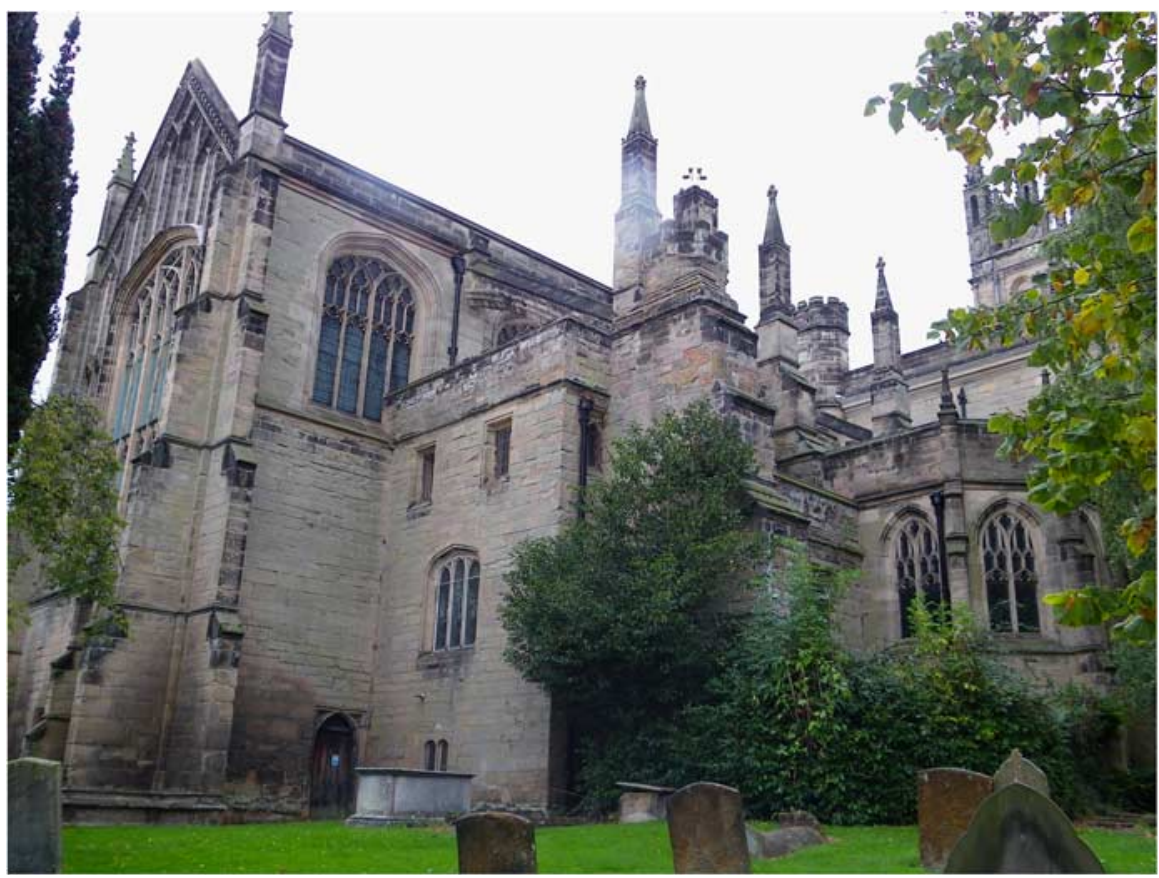

Fig I. St Mary's, Warwick, from the north east, showing the vestry and first-floor sacristy (centre) and chapter house (right). Photograph: author

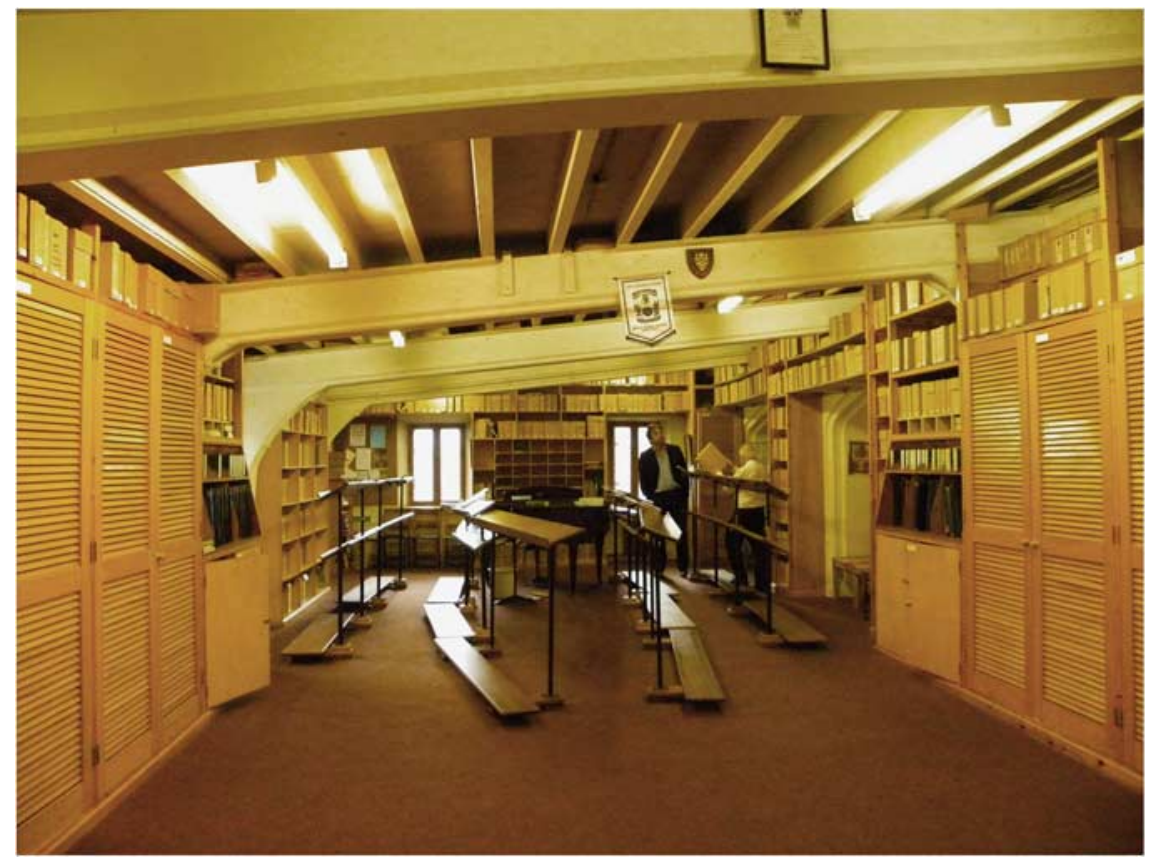

Fig 2. The medieval sacristy, now in use as a song-school. Photograph: author 


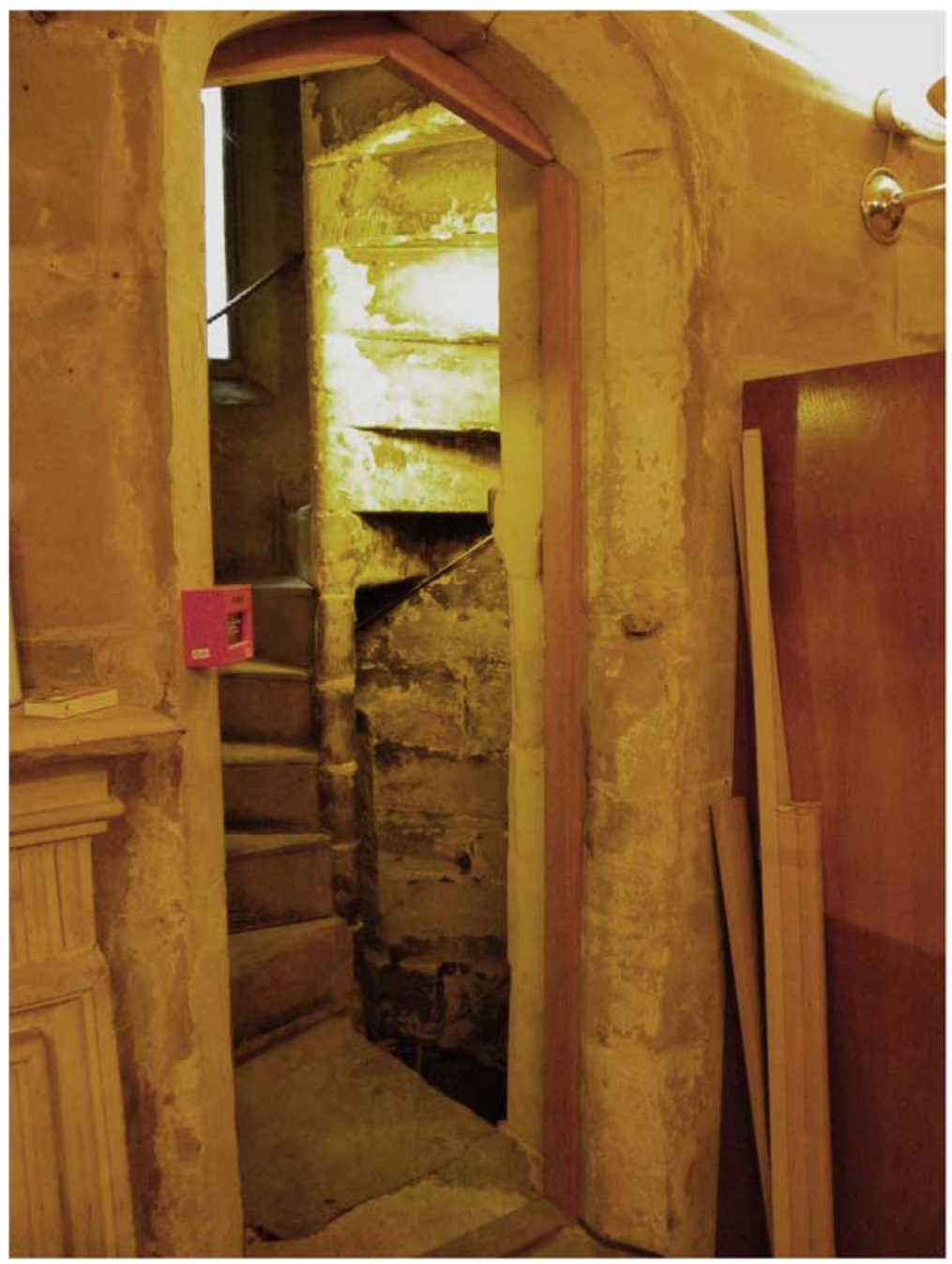

Fig 3. The vice in the north wall of the vestry. To the left is the Victorian mantle of the medieval fireplace. Photograph: author

The most surprising feature of the arrangements is the provision that, for the safe keeping of the treasures and also to be better available when needed, Hillusley was to sleep in the sacristy. He was to come to his bed 'euery nyght at due tyme in somer by the clere light of the day', and in winter by seven o'clock at the latest. If he had good reason to be absent, perhaps through sickness, and his absence had been approved by the dean and chapter, then it was incumbent on him 'at his peril' to provide a deputy who would sleep in the church in his place. The principle is clear that this medieval burglar-alarm should be reliably available every night. And for the further security of the treasures, Hillusley was forbidden to bring any outsider into the 'secretness' of the place. The importance of the role must have been significantly increased by the superb gift of treasure the college had recently received from Richard Beauchamp, earl of Warwick (d I439), whose memorial chapel in the 


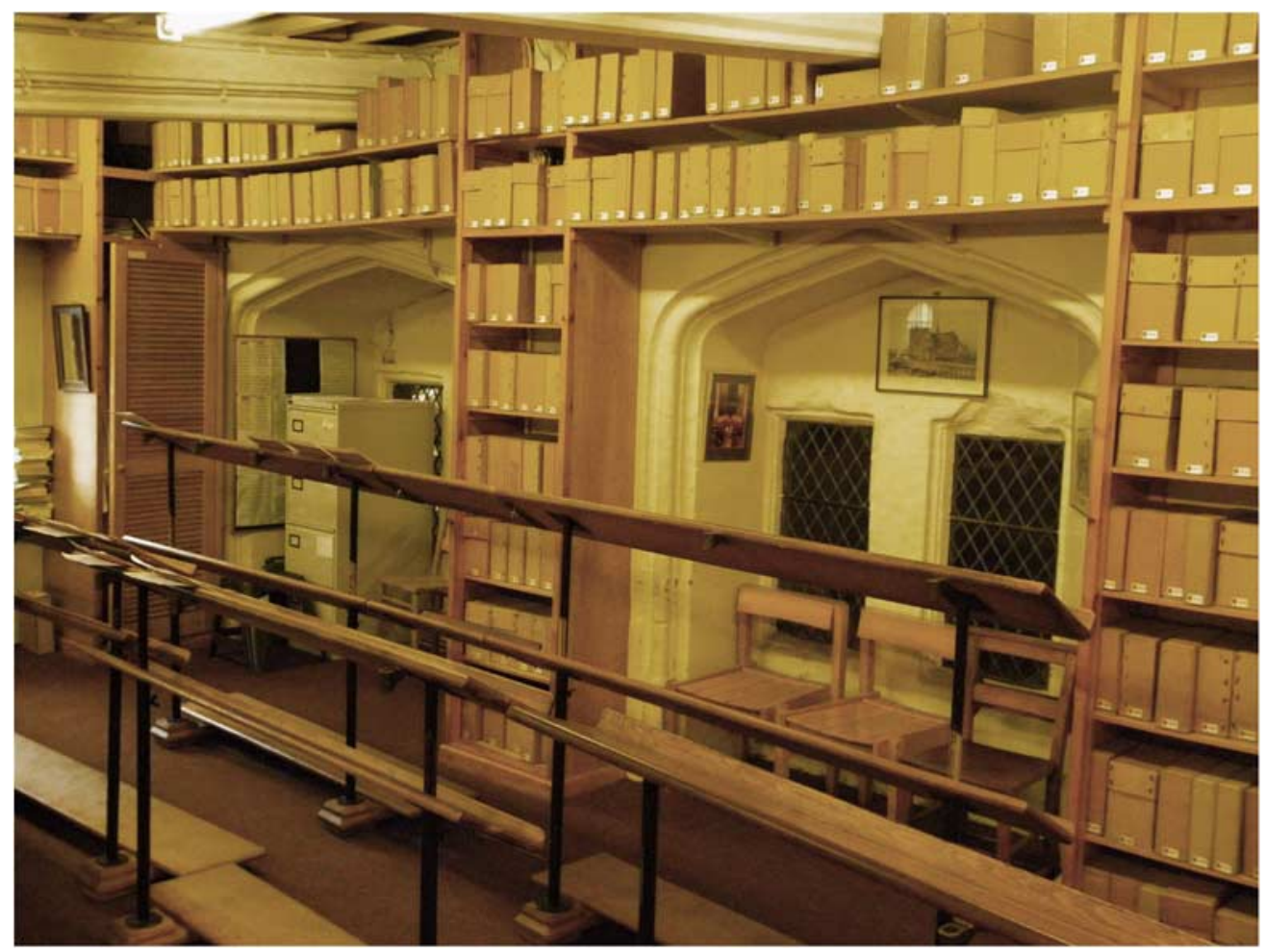

Fig 4 . The squints in the south wall of the sacristy. Photograph: author

church stands as the apotheosis of late medieval commemorative art. ${ }^{8}$ An inventory taken in I 468 of these treasures is stitched to the foot of the inventory already mentioned; Hillusley was still the sacristan at that time. ${ }^{9}$ The salary was a generous sixty shillings a year. ${ }^{\text {IO }}$

The sacristy that Hillusley knew still exists at St Mary's. It had recently been moved to a position over the vestry on the north side of the choir, east of the chapter-house, when its previous place on the south side was taken by the new building of the Beauchamp Chapel (fig I). It is a long chamber, 6oft in length by $18.5 \mathrm{ft}$ in width ( $18 \mathrm{~m}$ by $5.6 \mathrm{~m}$ ), cut into since the I 970 s by a staircase vestibule on the north side with partition walls carving out a small store-room at the western end. Its ceiling is modern (fig 2). Direct access from outside was originally gained by way of a door from the cemetery that opens into a lobby, and then by a vice in the north wall near the east end of the vestry (fig 3). To the west, an internal door opens from this ground-floor vestibule into the church. The present door is post-medieval, but if it were a replacement for a medieval door then the arrangement would suggest itself as a security feature, for with that door locked, the vestry could be internally secured from the rest of the church.

8. The Beauchamp Chapel has been discussed on numerous occasions; for orientation, see most recently Marks 2010.

9. The inventory was printed in its entirety in [Bloxam] $1847,56-60$.

IO. According to payments recorded in the treasurer's accounts: Styles I969, 22, 47. 


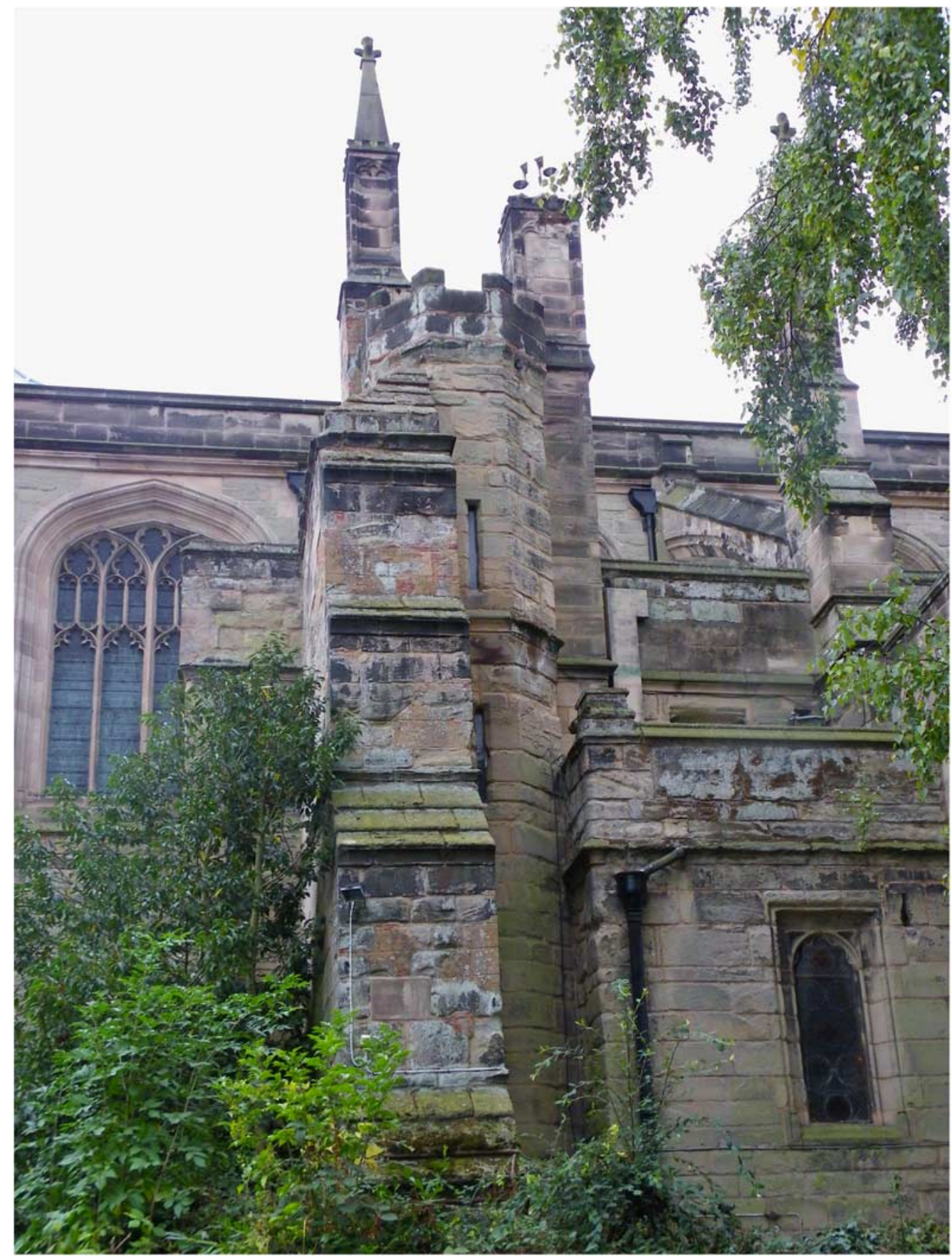

Fig 5. Exterior of the sacristy, showing a buttress, stair turret and chimney. Photograph: author 


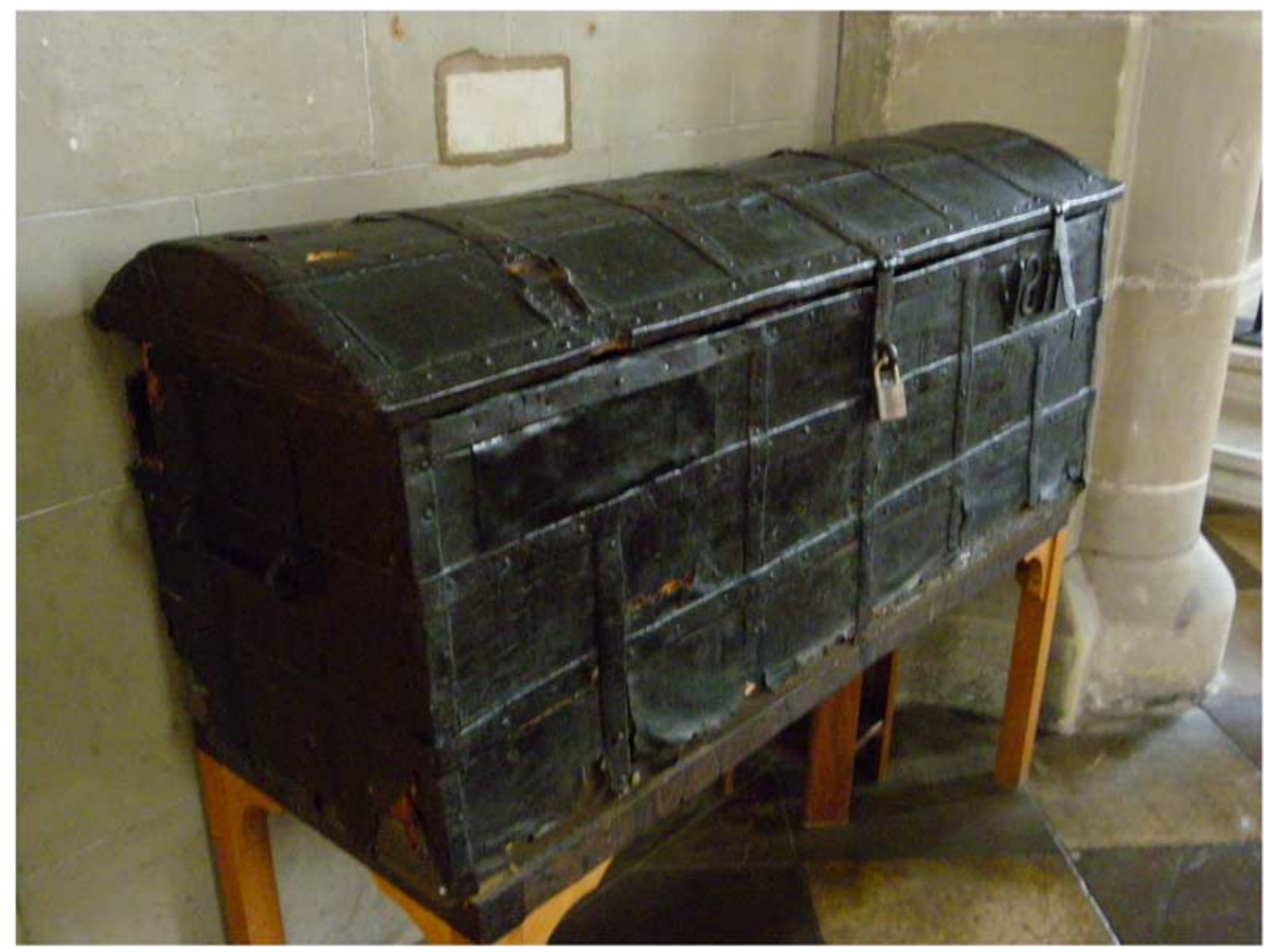

Fig 6. The possible treasury coffer. Photograph: author

This first-floor sacristy room was furnished with a fireplace in the north wall, which might have been intended for the comfort of the resident sacristan, but seems instead, and more plausibly, to have been lit when the earl and countess came to this private space to hear matins and vespers. ${ }^{\text {II }}$ The external churchyard door would have granted them access to this private pew. In the south wall are two large, handsomely made apertures, each with two squints, by which the activity of the choir could have been observed (fig 4 ). There are two small, square-headed windows at the east end and two on the north side.

The inventory taken at the time of Hillusley's appointment in 1465 describes the chests and cupboards that were in this 'sacristy above the vestry' (the evidence is printed below in Appendix 2). It is clear from the description of this furniture that this space was what Bourgchier's statutes had referred to as 'the treasury', and it also reveals that the chamber was internally partitioned, for it contained an 'inner house'. ${ }^{\text {I2 }}$ In this inner house

II. The fireplace is now walled up and invisible, but was mentioned in the treasurer's account for I454-5: PRO, Special Collections: Ministers' and Receivers' Accounts, SC 6/104I/3, m. 5; Styles I969, 60. Two cartloads of fuel were bought that year to feed the fire in camino supra le vestiary coram Domino et Domina ibidem existentibus ad audiendum missam matutinas et vesperas per diversas vices hoc anno ('in the fireplace above le vestiary for my Lord and Lady, they being there to hear mass, matins and vespers at various times this year'). There is no piscina in the sacristy, but there was one, now partially obliterated, in the vestry below.

I2. PRO, E I54/I/46, m. 3 dorse. 
was one new, tall cupboard with two doors for the college muniments, along with 'one great old ark' and certain other old cupboards ('almaries'). The medieval staircase access was at the east end, which is where the squints and fireplace chimney also cluster (fig 5); one may speculate then that the 'inner house' was at the west end of the room.

In the main part of the room there was 'one old ark' at the east end, certain cupboards, one old coffer bound in iron with a 'long lock of the old fashion', and one smaller and newer coffer with three locks, called 'the treasury coffer'. A chest matching this description, covered in leather and bound with iron, is still in the church at St Mary's, standing at the eastern end of the north aisle (fig 6). As has already been mentioned, the treasury coffer with three locks was enjoined upon the college by Bishop Bourgchier's statutes of I44I, to be kept in the treasury. Its appearance in the inventory is additional evidence that the dean and chapter were attentive to his injunctions, and its presence in this space determines that the treasury and sacristy occupied the same space in this first-floor room.

The office of sacristan had some prior history at Warwick. By the early fifteenth century it had become separated from the office of canon treasurer (a dignity created by Bishop Whittlesey's ordinances of 1367), to whom, however, the sacristan remained responsible. ${ }^{13}$ An inventory drawn up at the Feast of the Purification in 1408 names as sacristan John Besseford, a chaplain of Warwick who was presented to the vicarage of Whittlesford (Cambs) in I423. ${ }^{\mathrm{I}}$ An addition at the foot of the document reveals that the inventory was used again in 1409 when the sacristan was Henry Derleston, who had been appointed in a ceremony on 9 October when Derleston's father and three local worthies stood surety for him. ${ }^{15}$ Although friends were called in to stand as bondsmen for Derleston there is no evidence to show that the sacristan so appointed was required to sleep with the treasures (this earlier inventory is replete with such treasures). Hillusley's investiture is the only occasion when the sacristan's oath was written down in a way that allowed its transmission. In the oath's adherence to the spirit of Bishop Bourgchier's injunction of I44I that the treasures be kept securely, paying a man to sleep in the sacristy might well have been a new custodial arrangement, designed to promote prudent accountability.

An institutional setting for the taking of oaths is visible at Warwick. By making these pledges, members of the collegiate foundation of whatever rank were bound in to the life of an increasingly devolved and complex collegiate foundation in a way that made them legally accountable for their behaviour. Under Whittlesey's ordinances of 1367 the dean and canons were all to swear to obey the diocesan, while new, more elaborate, oaths were devised for the dean and canon treasurer. ${ }^{\text {I6 }}$ Under Bourgchier's statutes of I44I, oath-taking was enjoined on all ranks of the foundation, from the dean and canons to the vicars and 'lesser ministers', none of whom could enter into the emoluments of their

13. The office of sacrist, as distinct from the lowlier position of sacristan, went back apparently to the beginnings of the church in the I2th century, and in these earlier times the sacristan also maintained some responsibility for general financial administration: Styles I969, xxiii-xxiv; adjusted by Fonge 2004, xliii, lii, lvi. For the creation of the dignity of treasurer in 1367 , see Whittlesey's statutes: Fonge 2004, I52-3 (no. I24). By I408, the date of the inventory mentioned below, the sacristan had only the custody of the chapel goods.

I4. Cartulary of the college (as above, n 3), fol Ioov; Fonge 2004, 205 (no. I78). Extracts from the inventory (service books and relics) were printed by Dugdale 1730, 433; followed by Cox 1908, 127-8. The entire document was printed by Fonge 2004, 333-42 (no. 32I). The church of Whittlesford had been appropriated to the college in $1392 \times 1395$ (Fonge 2004, liii).

I5. Cartulary (as above, $\mathrm{n} 3$ ), fol 204v.

I6. Fonge 2004, lii, lvi-lvii, I5I-3 (no. I24e-f). 
position without first having sworn the oath in person, on a gospelbook (Hillusley reportedly used a missal). The terms of Hillusley's oath reflect the tenor of these others in its injunction to 'kepe secret and priue alle the secrete counselles and ordinaunces that I shal knowe'. Keeping the secrets of the place is a term of the dean's oath, of which the (Latin) text survives. The other oaths that followed it are now lost where the manuscript breaks off, but a separate document of 1446 records the tenor of the vicars' pledge; this too, like the sacristan's oath, bound them to revere the dean and chapter and keep the college's secrets. ${ }^{17}$ Hillusley's was the more elaborate oath since it specified his duties.

Having identified the way in which the dean and chapter at Warwick secured their treasures, it is natural to wonder whether similar arrangements existed at other great churches. Certainly, it was a requirement of the Victorine order, as defined in the twelfthcentury Liber ordinis of the abbey of Saint-Victor in Paris, that the canon-sacrist and his assistant, the matricularius, as well as a third man appointed by the abbot, spend each night in the church for the security of the place. ${ }^{18}$ Other Augustinian houses followed suit, such as Barnwell priory in Cambridgeshire, where the custumal is transmitted by a manuscript dating from around 1295. ${ }^{19}$ At Worcester cathedral priory, the sacrist was assigned to a house that was attached to the north side of the choir, built shortly before I335 (demolished in I7I2-I5). It was of three storeys and had a polygonal oriel window opening into the choir, overlooking the shrines of Oswald and Wulfstan. ${ }^{20}$ The arrangements at Worcester are particularly germane given that St Mary's, Warwick, was one of the great churches in that diocese and that improvements to her custodial arrangements had been implemented after episcopal visitation.

For collegiate churches in general, matching evidence is harder to find. At least one other college had adopted arrangements like those in place at Warwick, for a visitation of the college of St John the Baptist at Stoke-by-Clare (Suffolk) on Io July I532 heard that the sacristan was not sleeping in the vestry as was his duty. ${ }^{21}$ For other collegiate churches the hints are architectural. At the former collegiate church of Holy Cross at Crediton (Devon) may be seen a building towards the south-eastern end of the church, abutting the south choir aisle halfway along its length, that is understood to have contained the collegiate chapter-house on the ground floor, where there is now a vestry. The building has three floors and there is an exterior door to the churchyard connected by a small vestibule to the stair turret. The second-floor chamber, known as the Governors' Room, has a squint that allows a view of the high altar. The parallels with the situation at Warwick are suggestive.

The other great collegiate church in Devon, at Ottery St Mary, bears similar points of contact. Two vestries were added against the choir aisles, north and south, halfway along the

I7. Statutes, 30; Fonge 2004, 394-5, and lxiii for the vicars' oath.

18. Liber ordinis sancti Victoris Parisiensis, ch 21; Jocqué and Milis 1984, 94-6, at 96; also Jocqué I99I, 80-I.

19. Here, the sacrist and matricularius were not only to pass every night in the church but also take their meals there: Observancie regulares, ch I5; Clark I897, 68-78, at 74. The matricularius was further enjoined to examine the church in its every part at night when the time came to lock the doors.

20. I owe this observation about Worcester to the kindness of Joan Greatrex. For a description of the sacrist's house, and for details of an armed raid in 1355 and the theft of muniments, books and jewels, see Engel 2007, 29 and n 8.

2I. Item dicit (sc. Magister Iohannes Keyll) quod custos vestiarii non cubat singulis noctibus in vestiaria iuxta iniunctiones prius factas ('Item [Master John Keyll] says that the keeper of the vestry is not lying every night in the vestry, as he should according to previous injunctions'); Jessopp I888, 299. 
length, in the same position as at Crediton. ${ }^{22}$ The inspiration would certainly have been taken by Crediton from Ottery, since the Ottery vestries were put up a century earlier, by John de Grandisson (1292-1369), bishop of Exeter. Each vestry has an upper chamber, accessed by a narrow stone staircase in its western wall. The vestry on the south side shows an aperture on its northern wall for a fireplace and chimney. The treasury, however, seems to have been the upper chamber on the north side - an arrangement echoing that at the cathedral - where there are niches built into the western wall to take aumbries for such ornaments and plate as were not in constant daily use in the choir. However, neither vestry has external access; the churchyard door to the south vestry is an insertion of the eighteenth century.

At St Peter's, Irthlingborough (Northamptonshire), the striking west tower stands at a little distance from the west end of the church and is connected to it by two sections of building, originally part of the collegiate ranges, all belonging to the time of the college's foundation in the 1360 s. $^{23}$ The tower is of four stages and is crowned by a substantial octagonal lantern of two stages. Internally the lantern has three storeys connected by staircases in the thickness of the walls, and the lower- and upper-most chambers had fireplaces. ${ }^{24}$ It would be a plausible suggestion that the tower was used as the college's treasure house and muniment room, and was so built to be inhabitable by a resident custodian or sacristan. Another example, the collegiate church of St Mary the Virgin, St John the Baptist and St Andrew at Wingfield (Suffolk), was substantially remodelled in the $\mathrm{I} 460$ s by Alice de la Pole, duchess of Suffolk. ${ }^{25}$ The remodelled vestry includes the striking feature of an external door to the churchyard and a painted wooden gallery to the interior, which, to judge by the external chimney-stack, was once heated by a hearth. It has been argued that this was a private watching-loft for members of the de la Pole family, which would align with the evidence of the earls of Warwick having used the sacristy altar at St Mary's as a private chapel. ${ }^{26}$ However, there is no corresponding loft at the de la Pole foundation at Ewelme (Oxon), whose architecture otherwise mirrors Wingfield's so exactly (and where the adjoining almshouse would have provided an alternative venue in which to secure valuables). It is also curious that the single aperture on to the high altar should only be large enough for one person at a time to have a view. While the idea carries weight that this chamber at Wingfield was intended to offer privacy to the aristocracy, the possibility that it was also intended for a resident sacristan cannot be excluded.

What all these colleges have in common is that the canons' or fellows' lodgings were at some distance from the church, and their premises lacked the security of shared space and cloistered enclosures that were a feature of the common life of some other colleges. ${ }^{27}$ There would have been no need for an inhabited sacristy at either Winchester College or New College, Oxford, where the founder, William of Wykeham, placed the treasury and muniment tower at the centre of the buildings, the ranges wrapping around to form in

22. Dalton I9I 7, I5-16, 65-6. The inspiration in turn for these buildings at Ottery was Grandisson's projecting chapels at his cathedral in Exeter, of St James and St Thomas on the south side and St Andrew and St Katharine on the north.

23. On the history of the college's foundation at Irthlingborough, see Thompson 1919-20.

24. One notes that only one fireplace would be needed to kindle incense, as was Dalton's suggestion for the fireplace at Ottery.

25. Goodall 2003.

26. Goodall 2000, 52-5.

27. At Warwick, the college house and deanery had been recently rebuilt by Dean Berkeswell in the south-eastern corner of the churchyard; Leland described the buildings so (Toulmin Smith I906-IO, v, pt II, I53). 
each case a secure precinct. Likewise, a college standing within the walls of a castle, such as the chapel of St George at Windsor (Berkshire) or St Mary's College at Mettingham (Suffolk), might judge itself to be secure enough. ${ }^{28}$

These examples of potentially inhabitable sacristies are conjectural and are not based on a systematic search. For the sacristan's responsibilities at Warwick, however, the documentary evidence combines with the architectural to reveal a custodial practice that can be firmly substantiated. While it is, by that same token, locally particular, architectural evidence suggests that it was a practice that found its echo elsewhere, and we might assume that it found its echo quite widely.

\section{ACKNOWLEDGEMENTS}

I am very grateful to this fournal's anonymous reviewers for their careful and constructive reading of this article. Mr Alan Baker, Deputy Custos and Music Librarian at St Mary's (and modern-day sacristan), kindly showed me over the church.

\section{APPENDIX I}

The oath printed here was that taken by Thomas Hillusley on 22 February $1464 / 5$ when the goods of the church were entrusted to his care; it is transmitted on the dorse (m. 2) of the inventory taken at the same time (now PRO, Exchequer, King's Remembrancer, Inventories of Goods and Chattels, E I54/I/46) ${ }^{29}$ The scribe was the same man responsible for the inventory, using the slightly browner ink and thinner pencut of the latter part of this long inventory. This original, which is indented along its left-hand edge, may be collated with a copy made in I69I by Humfrey Wanley in an early facsimile book of charters and documents, several of which concern Warwick (now BL, Harley MS 7505, fols $3-8 \mathrm{v}$, the oath at fol $7 \mathrm{v}$ ). There are sufficient orthographical differences between the copies to suggest that Wanley was working from a different exemplar; indeed, while there are emendations common to both witnesses, as accessions and de-accessions were recorded over time, the copy among Exchequer records in the PRO shows changes that were not entered in Wanley's exemplar. The Exchequer document is the right-hand part of an indenture; Wanley's exemplar was presumably the indenture's other half, now lost. As has been mentioned already, Bishop Bourgchier's statutes enjoined that one half of any indented inventory was to repose in the chest with three locks, the other in the hands of the sacristan. The two halves were clearly kept up in parallel for a time, but only the Exchequer copy maintained currency, which suggests that it was the half of the document used by the sacristan.

Wanley stated that his copy had been made from an original 'in ye Custody of Mr Fish of Warwick'; this is James Fish the elder (d I702), formerly the schoolmaster at Warwick, parish

28. Notwithstanding, at St George's Chapel men were set in the church to watch the relics on the days when they were brought out for veneration, and on Relic Sunday (a local tradition) a clerk was set to guard the relics overnight, no doubt along with the offerings of gold and silver that had yet to be taken into the treasury (Precentor's Roll for 1396-7, Windsor, Dean and Chapter Archives, XV.56.I5; see Bond 1947, 283). These arrangements were, of course, occasional.

29. The inventory was part printed from Wanley's copy in [Bloxam] I847, I4-20. The oath was noticed by Styles (1969, xli), but it has not hitherto been printed. 
clerk of St Mary's and keeper of the Beauchamp Chapel and its records. ${ }^{30}$ Wanley met $\mathrm{Mr}$ Fish on 30 August 1694, to judge by the date of his draft catalogue of the muniments, which therefore records the state of the archive less than a week before the great fire of Warwick. ${ }^{3 \mathrm{I}}$ In October Wanley was back again, to see what had been lost and to pursue enquiries for the Catalogi librorum manuscriptorum Angliae et Hiberniae, published in 1697-8. His published report on St Mary's shows that at that time the inventory was still in Fish's hands, one of thirty-two items from the former college, ranging in extent from single pieces to collections of charters. ${ }^{32}$ After Fish's death the manuscripts passed to his son, and in I72I Wanley was negotiating with James Fish junior to buy them for the Harleian Library. ${ }^{33} \mathrm{He}$ was not successful and the whereabouts of the documents are now not known.

- Here foleweth in writing the oeth and the articles of the same oeth, the whuche I Thomas hillusley haue made and sworne vppon a masseboke and on my holydom' the friday the xxij. day of Feuerere the fourthe yer of kyng Edward' the fourthe and of oure lord $\mathrm{M}^{1}$. CCCclxiiij.

I I Thomas hillusley shalbe trewe and obedient to the Dean and chapitre of the chirche collegiat of Warrewyk and to theire successours in alle lawfull' and honest thinges at alle tymes fro this day forwarde as longe as I shal haue and kepe the office of Sexteyn in that chirche.

T Also I shal save and kepe wel and truly to suche vse and occupacion' and vnder suche maner and wyse as the forseide Dean and Chanons of the same chirch therynne beynge resident wole ordeyne and enisyne to me al maner money, iewels, bookes and vestymentes and al maner other stuf and godes belongyng to the seide Dean and Chapitre and to the seide chirche that shal come to myne handes and keping in places ordeigned in the seid chirche to kepe alle suche godes inne. And that I shal neither delyuere oute ne leue ne ley to wedde to ony persone ony maner stuff or good belonging to the seid chirche ne receyue ne take to kepe into that chirche ony mannes good withoute the speciall' assent and commaundement of the forseide Dean and Chanons.

- Also I shal attende and be redy in my persone at alle tymes in the forseide chirche to ministre and to doo wel and diligently al maner besynesses, occupacion and seruice that shal belonge to the forseide office of Sexteyn fro tyme to tyme, but if I haue lettyng resonable suche as the forseid Dean and Chanonns wole approve, and then I shal fynde a nother man at my perille to done al that I shulde done during myne absence.

- Also I shal procure, awaite, and doo in alle that I shal conne and mowe the honour and profite of the forseide Dean and chapitre and chirche in euery wyse at alle tymes in the excercease of the forseide office of Sextein.

30. The documents concerning his appointment as keeper are laid out by Dugdale 1956, I6-22. A discussion of Wanley's dealings in Warwick is in preparation by Julian Munby, FSA.

31. Bodleian, Ms Rawl D. 868, fols 65-66v. On the fire, see Farr 1992.

32. CMA 2/I, 203-206, nos 6683-6715.

33. Wright and Wright I966, I, 83. 
And if I may knowe ony thing that shall' sowne to the dishonoure or harme of the seide Dean and Chapitre or Chirche I shal withstande and let it with al my power and in alle haste certifie them therof truly and playnly.

- Also I shal do my true seruice diligently to geder up al maner of offeringes and al maner other dutees in the forseide chirche that the Sexteyn there hath be accustumed to geder. And I shal delyuere it wholly to the Tresorer of that chirche or to his deputee withoute a menesyng therof in ony wyse whenne it is asked.

T Also for the sauf garde of alle the goodes here afore specified and also to be redy when I am called, I shal be and ligge contynuelly euery nyght withinne the forseide chirche in the place that is ordeigned for the Sexteyn there, of lasse then siknesse or ony other cause resonable suche as the forseide Dean and Chanons wole admitte and licence me to make me ligge in other place, and then I shall' fynde at my perille an other man to ligge there in my name and place as ofte as it shal soo happe. And I shal vse neither tavernes, dise playng, huntyng, fisshing ne ony other vnthrifte or riottes rule, ne were neither bolsters in my clothing ne pikes on my shoos ne longe dagger, but I shal araie me like a Clerk to serue god, and were habite and helpe $\backslash$ to sey/ 34 and syng diuine seruice there diligently fro tyme to tyme as I shal mowe to attende therto for other bysynesse of my seid office. And also I shal come to the seide chirche to my bed euery nyght at due tyme in somer by the clere light of the day, and in wynter at vij of the clokke at the ferthest, and noo persone ne persones bringe into the Sextre or Vestre there to see the secretenesse of the place for ony cause herafter. Also I shall' kepe secret and priue alle the secrete counselles and ordinaunces that I shal knowe touching the Dean and Chapitre of the forseide chirche, and not discouere ne opene hem to the hirte, harme, reproef or shame of the seide Dean and Chapitre or of ony of them.

\section{APPENDIX 2}

An inventory of the goods of the church was taken at the time Thomas Hillusley took up post in 1465 (as discussed above), which included a survey of the furniture of the sacristy. This portion of the inventory is excerpted here for the information it offers on arrangements in the sacristy (using PRO, Exchequer, King's Remembrancer, Inventories of Goods and Chattels, E I54/I/46, m. 3 dorse).

- Item in the Sextry aboue the vestrye is $j$. olde arke at the auters ende, $j$. olde cofre irebounde hauyng a longe lok of the olde facion, and $j$. lasse nyewer coofer hauyng iij. lokkes cald the Tresory coofre, and certein almaries.

- Item in the Inner hous $\backslash$ there ${ }^{35} \mathrm{j}$. nyewe hie almarie with $\mathrm{ij}$. dores to kepe the euidence of the chirche, and $j$ gret olde arke and certein olde almaries.

34. 'to sey': interlineation by the main hand.

35. 'there': interlineation by the main hand. 


\section{ABBREVIATIONS AND BIBLIOGRAPHY}

\section{Abbreviations}

BL

Bodleian

$C M A$

PRO

WRO
British Library, London

Bodleian Library, Oxford

[E Bernard and A Charlett], Catalogi librorum manuscriptorum Angliae

et Hiberniae in unum collecti, 2 vols (London I697-8)

Public Record Office of the National Archives, Kew

Warwickshire Record Office

\section{Manuscript sources}

BL, Harley MS 7505 (facsimiles by Humfrey Wanley)

Bodleian, Rawl D. 868 (antiquarian collections, including list of manuscripts at St Mary's in I694)

PRO, Exchequer, Court of Augmentations, Miscellaneous Books, E 315/492 (statutes of St Mary's)

PRO, Exchequer, King's Remembrancer, Inventories of Goods and Chattels, E I54/I/46

\section{Published sources}

[Bloxam, M H] I847. Notices of the Churches of Warwickshire, under the Superintendence of the Architectural Committee of the Warwickshire Natural History and Archaeological Society, I, Warwickshire Natur Hist Archaeol Soc, Warwick

Bond, M F 1947. The Inventories of St George's Chapel, Windsor Castle 1384-1667, Windsor: The Dean and Canons of St George's Chapel

Clark, J W I897. The Observances in use at the Augustinian Priory of S. Giles and S. Andrew at Barnwell, Cambridgeshire, Cambridge: MacMillan and Bowes

Cox, J C 1908. 'The college of St Mary, Warwick', VCH Warks, II (ed W Page), I24-9, London: Archibald Constable

Dalton, J N I9I7. The Collegiate Church of Ottery St Mary. Being the Ordinacio et statuta ecclesie sancte Marie de Otery Exon. diocesis AD I338, 1339, Cambridge: Cambridge University Press

Dugdale, W 1730. The Antiquities of Warwickshire, and edn, London: printed for John Osborn and Thomas Longman

Dugdale, W 1956. The Restoration of the Beauchamp Chapel at St Mary's Collegiate Church, Warwick 1674-1742, Oxford: Roxburghe Club (inventory of St Mary's, I465, with oath on dorse)

PRO, Exchequer, King's Remembrancer, Miscellaneous Books, Series I, E I64/22 (cartulary of St Mary's)

PRO, Special Collections: Ministers' and Receivers' Accounts, SC 6/104I/3

Windsor, Dean and Chapter Archives, XV.56.15

WRO, CR 26/4 (Black Book of Woodcote)
Engel, U 2007. Worcester Cathedral: an architectural history (trans $\mathrm{H}$ Heltay), Chichester: Phillimore

Farr, M 1992. The Great Fire of Warwick. 1694: the records of the commissioners appointed under an Act of Parliament for rebuilding the town of Warwick, Publ Dugdale Soc 36

Fonge, C R 2004. The Cartulary of St Mary's Collegiate Church, Warwick, Woodbridge: Boydell Press

Goodall, J A A 2000. God's House at Ewelme: life, devotion and architecture in a fifteenthcentury almshouse, Aldershot: Ashgate

Goodall, J A A 2003. 'The architecture of ancestry at the collegiate church of St Andrew's, Wingfield, Suffolk', in Family and Dynasty in Late Medieval England: Proceedings of the 1997 Harlaxton Symposium (eds $\mathrm{R}$ Eales and $\mathrm{S}$ Tyas), I56-7I, Donington: Shaun Tyas

Haines, R M 1965. The Administration of the Diocese of Worcester in the First Half of the Fourteenth Century, London: SPCK

Jessopp, A (ed) I888. Visitations of the Diocese of Norwich, AD 1492-I532, Camden Soc, new ser, 43, London 
Jocqué, L i99i. 'Les structures de la population claustrale dans l'ordre de Saint-Victor au XIIe siècle. Un essai d'analyse du Liber Ordinis', in L'Abbaye Parisienne de SaintVictor au moyen age (ed J Longère), 53-95, Turnhout: Brepols

Jocqué, L and Milis, L 1984. Liber ordinis sancti Victoris Parisiensis, Corpus Christianorum Continuatio Medievalis 6I

Marks, R 20I0. "“Entumbid right princly": the Beauchamp Chapel at Warwick and the politics of interment', in Memory and Commemoration in Medieval England (eds C M Barron and C Burgess), I63-84, Donington: Shaun Tyas

\section{RÉSUMÉ}

Il reste une transcription d'un serment prêté en I465 par le sacristain laïc de l'église collégiale de St Mary, à Warwick, à l'occasion de sa prise d'office. Ses devoirs, indiqués en détail, comprennent la nécessité étonnante qu'il passe chaque nuit dans la sacristie afin de protéger ses trésors. Ce document, qui contient le serment, vise à le situer dans son contexte institutionnel. La sacristie médiévale de Warwick est intacte. Les détails du serment renvoient à des détails architecturaux. Des sacristies similaires situées au premier étage se retrouvent ailleurs. Il est suggéré que d'autres églises ont pu également avoir des sacristies habitées.
Styles, D 1969. Ministers' Accounts of the Collegiate Church of St. Mary, Warwick I432-85, Publ Dugdale Soc 26

Thompson, A H i919-20. 'The early history of the college of Irthlingborough', Associated Architectural Societies' Rep Pap, 35, 267-92

Toulmin Smith, L 1906-IO. The Itinerary of Fohn Leland in or about the Years 1535-I543, 5 vols in I I pts, London: G Bell

Willoughby, $\mathrm{J}$ forthcoming. The Libraries of Collegiate Churches, London: British Library Publications

Wright, C E and Wright, R C 1966. The Diary of Humfrey Wanley, I715-I726, 2 vols, London: Bibliographical Society

\section{ZUSAMMENFASSUNG}

Es existiert die Niederschrift eines Eids, der I465 vom Laienküster der Stiftskirche St. Mary in Warwick bei seinem Amtsantritt geschworen wurde. Es sind darin seine Aufgaben in allen Einzelheiten aufgeführt, unter anderem auch die erstaunliche Anforderung, dass er, zum besseren Schutz der Kostbarkeiten, jede Nacht in der Sakristei zu verbringen hatte. In diesem Referat ist der Eid abgedruckt, mit der Absicht, diesen in seinen institutionellen Kontext zu stellen. Die mittelalterliche Sakristei in Warwick hat bis heute überdauert und Einzelheiten des Eids leuchten auch architektonische Details aus. Ähnliche Sakristeien im ersten Stock sind auch anderswo zu finden und es wird somit nahegelegt, dass andere Kirchen ebenfalls bewohnte Sakristeien gehabt haben könnten. 